\title{
Transversal views on work in agriculture
}

\author{
Benoît Dedieu* \\ INRA, Sciences for Action and Development Division, Theix, 63122 Saint Genès Champanelle, France
}

\begin{abstract}
Agriculture employs 1.3 billion people throughout the world. Changes to working conditions in agriculture are investigated by several disciplines that explore different themes. These themes are summarized here through two areas: one that focuses on the worker (employment, health and skills) and the other on work as a component of farming systems. The analytical frameworks and core research issues are described. This paper is designed to be a general introduction to the special issue of Cahiers Agricultures, entitled "Multifacet realities of work in agriculture".
\end{abstract}

Keywords: work / agriculture / employment / health / skills / organisation / farm models

Résumé - Regards croisés sur le travail en agriculture. L'agriculture emploie 1,3 milliard de personnes dans le monde. Les transformations du travail sont abordées par de nombreuses disciplines et déclinaisons thématiques. Nous proposons de présenter la variété des thématiques selon deux entrées : l'une centrée sur le travailleur (emploi, santé et compétences), l'autre sur le travail comme composante des systèmes d'exploitation. Les cadres d'analyse et questions centrales sont décrites. Ce papier se veut une introduction générale au numéro spécial de la revue Cahiers Agricultures « Multifacet realities of work in agriculture ».

Mots clés : travail / agriculture / emploi / santé / compétences / organisation / modèles agricoles

\section{Introduction}

Agriculture is one of the most important industries worldwide, employing more than 1.3 billion people (FAO, 2008) full time or part-time in association with other activities (hunting, trading, making crafts, etc.). Indeed, jobs in agriculture account for more than $26.5 \%$ of total employment (World Bank, 2018). This percentage is falling rapidly (having reached $45 \%$ in 2000 ). But the number of workers has remained relatively stable because of the demographic profile of rural populations: migration to cities is high, but so is the birth rate and the rural population still increases $(+0.2 \%$ per year $)$.

The percentage varies considerably between different countries and continents. In 2011-2013, agriculture employment represented 3\% of total employment in France, versus $72 \%$ in Uganda (World Bank, 2018). Sustainable Development Goal \#8 states that decent work stimulates economic growth, but in general, work in agriculture is certainly not considered as important as other sectors of employment, except when waves of migration from poor rural areas in southern countries spark political debate and question national identities in northern countries.

A broad range of disciplines address work in agriculture: economics, sociology, ergonomics, management sciences,

\footnotetext{
*Corresponding author: benoit.dedieu@inra.fr
}

psychology, education sciences or farming systems (Dedieu and Servière, 2001). However, an overview of the themes covered by these disciplines with respect to the agricultural sector and its drivers of change remains problematic. Furthermore, the usefulness of developing transversal views on work in agriculture that will enable discussions on its future at the farm, local or national levels is rarely mentioned in the literature. This was nevertheless the objective of the $1 \mathrm{st}$ International Symposium on Work in Agriculture held in Maringa (Brazil) in 2016 (Dedieu and Damasceno, 2016) and of the International Association that was set up following that event (IAWA, 2018). This special issue of Cahiers Agricultures (Dedieu et al., 2019) groups a selection of the primary papers presented at the Maringa symposium. In this introduction, we offer an expert overview of the principal areas of investigation that deal with work in agriculture. Our expertise is based on three pillars, the author having been a member of different collective expert groups involved in:

- conducting a textual analysis of the areas covered by presentations at the Maringa symposium (Malanski et al., 2018);

- a retrospective review of the areas explored by the Research, Education and Extension Network (REEN) on Work in Livestock, supported by the French Ministry of Agriculture (RMT Travail en élevage, 2019). This REEN aims to gather all the organisations concerned by this 


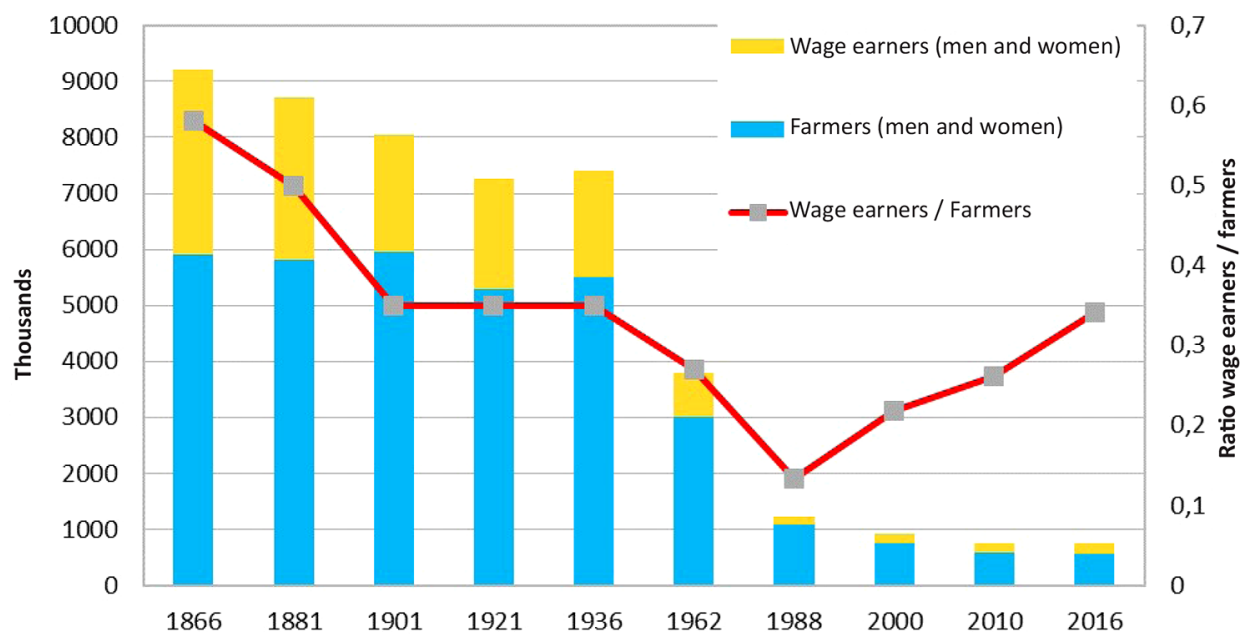

Fig. 1. Evolution of the numbers of farmers and salaried employees in France (men and women) and of the ratio wage earners/farmers (18662016) (Forget et al., 2019b).

Fig. 1. Evolution du nombre d'exploitants et d'employés salariés en France (hommes et femmes) et du ratio salariés/exploitants (1866-2016) (Forget et al., 2019b).

theme, develop shared expertise and drive research and extension actions to explore current hotspots. Over time (this REEN has been in existence for ten years), Work in Livestock has explored a broad range of topics that include the evaluation of work efficiency, the attractiveness of working on livestock farms or the diversity of operations by employer groups;

- collective expert report involving broad research participation, initiated by the French Ministry of Agriculture and focused on people and employment: "Actif Agri: Recompositions des emplois et du travail agricoles" (a study on the dynamics of employment and work in agriculture) (Forget et al., 2019a).

This expert contribution is supplemented by a typology of these different investigative areas, based on an extraction and analysis of ten years of Web of Science papers related to work in agriculture (Malanski et al., 2019b, accepted).

We summarize different aspects of work in agriculture from two standpoints: that of the worker (employment, health, skills) and that of work (workers, tasks) considered as a component of farming systems.

\section{Work from the worker's standpoint}

Two major issues are addressed: employment and health, alongside skills and career development.

\subsection{Employment}

Employment is, first of all, described using statistics in order to clarify the dynamics driving the number of workers in agriculture, the proportion of salaried employees and gender ratios. For example, Figures 1 and 2 show the statistics for France, the numbers being expressed as FTEs (full-time equivalents). These figures reveal:
- a standard and continuous curve showing the decline of jobs in agriculture since the 19th century and a recent trend which indicates an increasing proportion of salaried employees within the workforce. These statistics concern an OECD country where the enlargement of farms and increasing apparent labour productivity (AA/FTW - Agricultural Area per Full Time Worker) are important trends; this is not however the case worldwide, as rural demographics in most African and Asian countries are sustaining high employment on farms. Salaried employees account for $42 \%$ of all workers in agriculture at a global level (World Bank, 2018);

- a diminishing proportion of women working in agriculture. Increasing numbers of women are becoming involved in agriculture as individual entrepreneurs in France, but they certainly do not compensate for those retiring who were working on a family farm, and the numbers are generally much lower than for men.

The growth of salaried employment is not specific to France or other developed countries; it has also been described in the context of livestock farming in the Sahel region of Africa (Wane et al., 2018, in this issue). The contribution of salaried employees to work is a hotspot in the current literature. Their initial categorisation compares full-time to part-time workers, although other approaches have been developed, based on i) skills, responsibilities and activities on a farm relative to the needs of a specific sector (Nettle et al., 2018); ii) different types of contracts. Magnan and Laurent (2018) were able to distinguish 14 different types of workers in French agriculture who included seven types of salaried employees (Box 1). More generally, the issue concerns the insecurity of jobs for wage earners (part-time/ casual employment, or exposure to danger) and changes to their contracts. A few studies have explored the careers of salaried employees on farms (Malanski et al., 2019a). The recent growth of contractors (companies whose employees are contracted to 
complete specific tasks for farmers) was referred to in recent studies such as those by Nye (2018, in this issue), Anzalone and Purseigle (2015), Zhang et al. (2017) or Gras and Hernández (2014), which were carried out in the UK, France, China and Argentina, respectively. Outsourcing can cover a large number of tasks, ranging from harvesting and administrative work to integral management and work on arable farms. Collaborative work by several farmers is far less documented, although it makes an important contribution to achieving tasks that require large numbers of people and/or machines. Cooperation means that farmers can share equipment, infrastructures and increasing numbers of salaried employees, but it is also a lever to explore collective efforts to achieve agroecological transitions (Lucas et al., 2018).

Box 1. A typology of workers based on the contractualisation of labour (Magnan and Laurent, 2018).

Type 1: independent (farmer).

Type 2: permanent help from family members (who can benefit from social security coverage).

Type 3: permanent salaried employee (with a work contract)

Type 4: non-permanent-no wages (trainee). Working relationships involve the farmer, the trainee and the school/university.

Type 5: non-permanent (apprentice). The apprentice earns a wage, but is on a work/study programme.

Type 6: casual or temporary worker (two types of contracts for residents of the country with no permanent job.

Type 7: casual or temporary worker from another country.

Type 8: shared wage earners (groups of employers, machinery cooperative). The wage earner is employed by a third party and his working hours are shared by several farms.

Type 9: interim worker. Worker employed by a temporary employment agency.

Type 10: wage earners from a service-provider/ contractor.

Type 11: detached wage-earner. The employer is based abroad and sells a service or temporary employee to a farmer. The wage earner is dependent on the social security system in his country of origin.

Type 12: independent worker who does not have sufficient farming activity for his occupation to be recognized as a farmer. In France, these workers will benefit from the social security system for farmers.

Type 13: working under a specific agreement; WWOOFing is a good example. Work is seen as a learning opportunity in return for food and accommodation.

Type 14: illegal workers.

Many gender issues hide behind the statistics. Inequalities between men and women, changes to family relationships at work and to professional status (Dahache, 2014), the empowerment of women in rural areas and their contribution to development projects (Doss, 2018) are some of the topics currently under debate. The issue of empowerment is particularly important, as it highlights potential models for women in the future (Cornwall and Rivas, 2015).

Numerous other subjects are linked to employment, such as on- and off-farm work, its determinants and consequences (Owusu et al., 2011, for example), migration (e.g. Preibisch, 2010), successions (Bánkuti et al., 2018, in this issue), selling a farm or the early cessation of activities. In France, early cessations (before the age of 55) are quite common at present. They represent $30 \%$ of the total cessation of farmers between 2010 and 2015 (Mahé et al., 2019). They have become an important feature of agricultural economics. On the one hand, early cessation means that a farm becomes more similar to a commercial operation, where closing down and then starting a new business is common. On the other hand, the reasons for such a decision relate to the usual problems faced by farmers: a considerable workload for a low income, a high debt ratio, isolation, etc. Seasonal employment and migration appear to be major topics, the first dealing with the dependence of farming activities to abundant and low cost workforce in different regions of the world, the second highlighting that migrant workers (either seasonal or permanent) face very poor working conditions and numerous health and safety hazards (Svensson et al., 2013).

The drivers of changes studied are public policies, markets (local and international), rural dynamics, innovations (mechanization that now includes robotics) and the differentiation of food models (agroecological and local versus intensification and commodities). Public policies also play a major role through social, economic, health and land regulations (Zhang and Donaldson, 2010). Markets offer opportunities for the development of local or long marketing chains. There has been abundant literature on the impact of international markets on employment and workers' rights (Beaujeu et al., 2019; Blanpain, 2015), but the specific effects on food systems, including production, are rarely addressed. Innovations, precision agriculture and precision livestock management in particular, have radically changed the activities of farmers (notably with respect to animal husbandry), as well as their decision-making and skills (Butler et al., 2012; Hostiou et al., 2017). The research world has become very excited by the new information and decision-support systems enabled by new sources of data and digitisation. However, most of the precision tools often involve the use of increasingly large machines, or replace a worker (such as a milking robot). They therefore have a definite effect on gains in labour productivity and employment.

Finally, another common question concerns the effects of different farm models on employment. Do agroecological/ local or organic systems stimulate family employment, as opposed to intensive systems that target international markets and are reliant on high labour productivity (i.e. fewer jobs, fewer family workers and a higher proportion of salaried employees)? Authors such as Parodi (2018) explore these questions in this issue.

\subsection{Health}

Occupational health can be addressed from several viewpoints: musculoskeletal disorders, accidents, the impact 
of pesticides or dust (in poultry units) on workers' health, stress and suicide and working conditions.

Musculoskeletal disorders have been well documented by ergonomists who have developed methodologies and tests to analyse the effects of particular tasks on health (see Caldas de Oliveira et al., 2018, in this issue). There is considerable literature on this subject but this work is little acknowledged by agro-economists because it has mainly been published in medical journals.

Data on the injuries and deaths caused by animals or machines are dependent on the quality of their collection by health insurance and social security schemes. In France, where those involved in agriculture are managed by a specific mutualist system, there is considerable emphasis on preventive messages; deaths mainly appear to be related to livestock management (attacks by animals) or fodder machinery.

The effects of pesticide applications on the health of agricultural workers is a constant subject of debate. Collective expert reports have indicated that "there appears to be a positive association between professional exposure to pesticides and adult illnesses: Parkinson's disease, prostate cancers, lymphoma and other cancers" (INSERM Expert Report, 2013) but there is still "a lack of data on exposure to pesticides" (ANSES, 2014).

Stress and suicide are now considered as health issues in agriculture, notably in OECD countries. In France, the suicide rate among agricultural workers appears to be $20 \%$ higher than that seen in equivalent independent professions. Studies have now started to understand the factors involved in such tragedies. A recent study performed on farmers receiving support by solidarity associations revealed the multifactorial dimensions of their suffering: debt and low income; work constraints and familial pressures limiting life choices. The work constraints mentioned included long working hours, harsh conditions, isolation and an increasing administrative burden (Louazel, 2018). In this country, Deffontaines (2017) identifies 4 suicide categories: i) isolation (notably small farmers who stay single); ii) familiar net (tensions with the parents totally included in farm and the wife voluntarily at distance from the farming activity); iii) no future (loss of sense when nobody in the family is interested to settle); iv) downgrade (when insoluble financial difficulties cohabit with a high level of recognition by pairs).

Working conditions can be considered from two standpoints: acceptable/liveable working conditions which would mean working less, having more free time, taking holidays, reducing the harshness of conditions. Although there are marked differences in terms of the demands made by farmers (particularly the number of days of holiday), it is relatively simple to quantify and evaluate most of these elements. However, working conditions also affect mental health and self-fulfilment: building an identity, living together (with humans and/or with animals), permitting sensitivity and allowing skills to develop. Ultimately, working conditions need to meet production and time demands and promise subjective development (Fiorelli et al., 2010). Indeed, these authors proposed a grid to analyse self-fulfilment at work (Box 2) that has been used as a basis for some advisory tools.
Box 2. A grid to analyse subjective self-fulfilment at work on a sheep farm by part-time farmers (central France) (Fiorelli et al., 2010).

Economic rationality. Where sheep farming was expected to provide a principle or complementary income for the family or to simply self-finance farm operation.

Technical rationality. What is considered is the mastering of living entities and obtain access to a high level of productive performances. Some farmers also expressed their pride in being able to hold two jobs: "you have to be organised because you work during the week".

Relational rationality. Working with animals allow the farmers to positively invest their affectivity and sensitivity. By giving of themselves to the animals and receiving in return: "the animals get back what you give to them". But livestock farming appears as a time and space of shared pleasure, particularly with a spouse but also with other farmers at agricultural fairs.

Identity-linked rationality. The farmers emphasized the pleasure of doing a job where they could constantly learn and improve themselves, in contrast to some salaried jobs that provided no possibility of advancement: "livestock farming is a job where we continue to learn everyday". By taking up livestock farming, some farmers wanted to contribute to maintaining a family "heritage", going far beyond economic considerations. They wanted to ensure the continuity of raising animals, farming the land and preserving know-how.

Body-at-work rationality (to live outside, carry out physical work, good exercise): "[Livestock farming] changes your way of life", working more physically or differently and in a less monotonous way than at a factory job".

\subsection{Skills and professional development}

Skills are crucial when considering the career profiles on farms (notably for salaried employees) and in terms of the need for farmers to accept change, develop new abilities to manage the farm and adopt new perspectives. Skills can be seen as both knowledge and know-how. Research can make an important contribution to the former: enabling an ability to reinforce our understanding of the workplace and biotechnical advances and forecasting the effects of implementing new methods. However, knowledge rarely covers all areas of activity on a farm. Know-how is essential to both everyday working and in radically changing situations. Sharing experiences, testing and error management, as well as operational trials in situ can develop it (Chantre et al., 2015).

The particular case of a radical transition has been studied in terms of the resources that research can offer during the process. It is acknowledged that uncertainty is one of the characteristics of disruptive change and its mastery requires learning tools, the exploration of different scenarios and the sharing of experience on a step by step basis, including the confrontation of the desired situation and the realities (Fig. 3). 


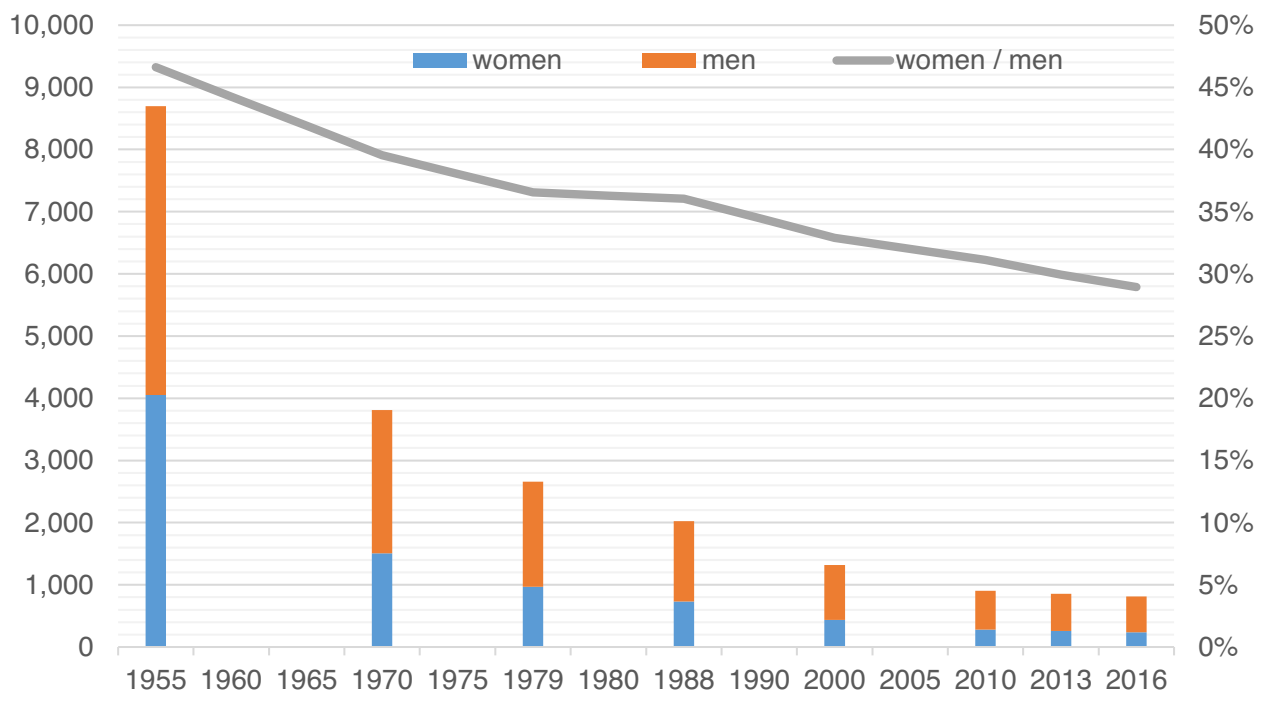

Fig. 2. Evolution of the number of permanent workers (men and women, in thousands) and the feminisation ratio of permanent workers in France, 1955-2016 (Forget et al., 2019a, b).

Fig. 2. Evolution du nombre de travailleurs permanents (hommes et femmes, en milliers) et du ratio de féminisation des travailleurs permanents en France, 1955-2016 (Forget et al., 2019a, b).

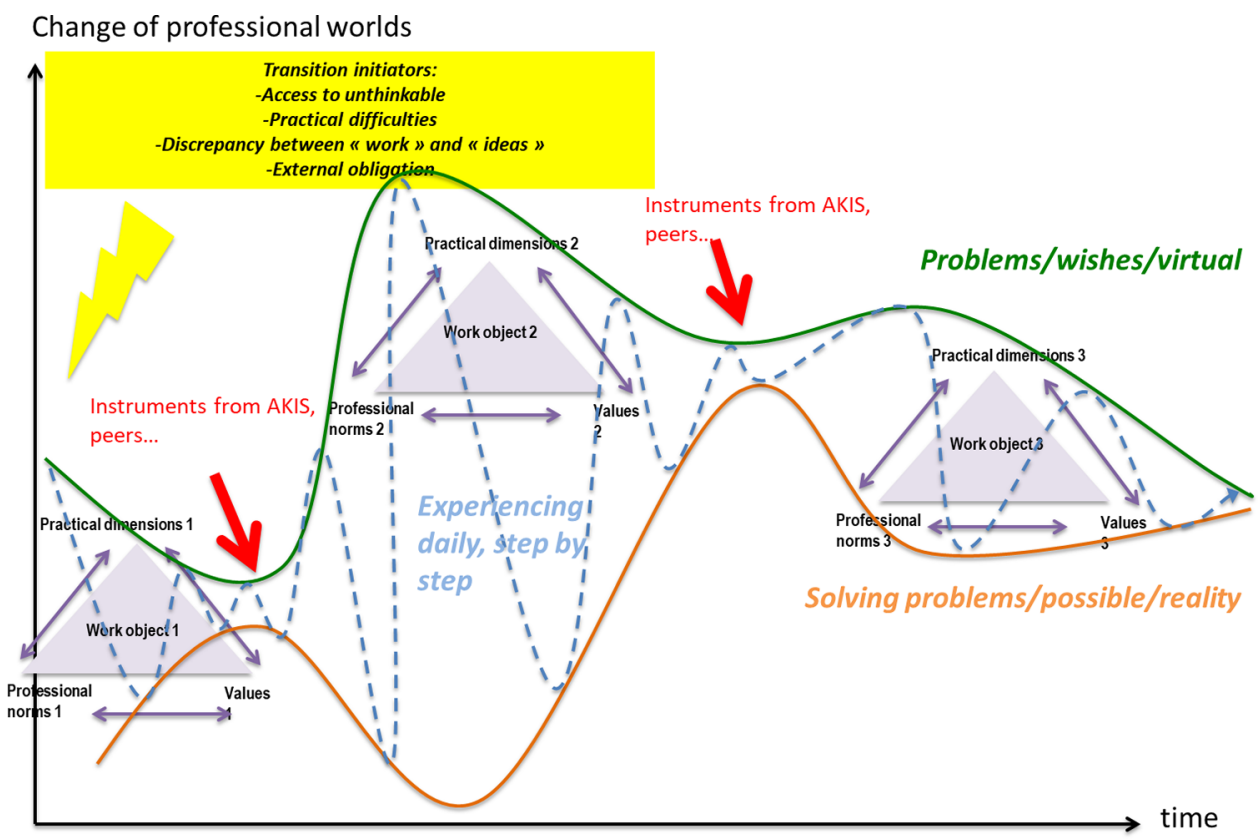

Fig. 3. Transition to radical change: step by step changes affecting work (Coquil et al., 2018a).

Fig. 3. De la transition au changement radical: les changements progressifs affectant le travail (Coquil et al., 2018a).

The process of radical change requires to build the work objects that need to be mastered, the indicators concerning the viability of the new system, related values (i.e. in terms of monetary value, gross margin, yield or autonomy) and to redefine the new sets of practices (Coquil et al., 2018a and b). Agroecological transition is a particularly well documented case in terms of investigating the professional development of individuals or groups of farmers, either with a new framework to support radical change (Chizallet et al., 2018 in this issue) or implementing tools to encourage the sharing of experience (Anglade et al., 2018).

\section{Work within farming systems}

In this section, workers and the workforce form an integral part of farming systems (Darnhofer et al., 2012). They are 
analysed in terms of their interactions with other elements that characterise the diversity and operation of farming systems. Sociologists have developed conceptual models of professional worlds (Hervieu and Purseigle, 2013) or farming styles (Van der Ploeg, 1994) that can be combined with the descriptors of farming systems. Scientists working on livestock farming systems have also generated other frameworks focused on the links between practices and tasks and considering the farmer both as a technical and economic manager and as a work organiser (Madelrieux and Dedieu, 2008).

\subsection{Work as a descriptor of professional worlds}

Hervieu and Purseigle (2013) proposed a categorisation of the farming profession based on the capital-land-work equilibrium, taking account of the composition of the workforce (particularly family and non-family members) and its organisation. They highlighted three main types (which were in turn divided into subcategories): firm, familial and subsistence. Dedieu and Damasceno (2016) illustrated these different models relative to work organisation. The agribusiness (company) system refers to farming at a very large scale, combining salaried employees, taylorism and high levels of mechanisation and outsourcing. The planning of crop rotations and technical operations is generally delegated, with agricultural work contracted to service providers and agricultural engineers. Their improvement makes reference to a sustainable intensification process. Very close to that firm model is the entrepreneurship model that associates family and salaried workforce, high technologies aiming at high labour productivity, where the farmer and highly skilled employees analyze and interpret increasingly more and precise information systems on crop and animal productions. The family model includes a family-based workforce alongside salaried employees and/or mutual aid, and a low level of mechanisation, although this will be more important when automated parlours replace hand milking (Baudron et al., 2019; Hostiou et al., 2012). Their marketing focuses on local food circuits and requires regular interactions with intermediaries or consumers (Parodi, 2018, in this issue). Their improvement process is based on the principles of agroecology. Finally, a community workforce with the sale of surplus products is a good illustration of the subsistence model.

The purpose of such studies is to clarify the dynamics and emergence of different farming models and to position workforce changes and work organisation traits within them relative to capital dynamics (i.e. Brignardello, 2018, in this issue). But these models do not only concern different types of knowledge. They can be used to support specific policies (for example, to encourage family farming in South America). They can also underpin political/professional debates on farm models that will be appropriate with respect to agricultural development and food security in particular countries. Some of them favour modernisation pathways (towards a company model) despite the efficient use of natural resources and risk resilience of traditional family-based systems. For instance, in Senegal, Diao-Camara (2013) showed how political/professional debate could exploit local know-how and traditional pastoral knowledge while at the same time (notably through land regulation) foster industrial/company models in order to meet production goals, finally considering that traditional systems are unable to feed the population and sufficiently increase supply.

\subsection{Dynamics of professional identities}

The farming styles (Van der Ploeg et al., 2009), although not materialising all the diversity of the farmers' logics, convey relationships to work. These relationships are questioned in the face of multiple and sometimes contradictory injunctions. Between those defining a modernization model as it is the case in many developing countries, and those advocating new technologies such as precision agriculture or agri-environmental measures, all strongly push to revise the existing technical models. These watchwords convey considerations on farmers - and rurality more broadly - and are factors of transformation. To look at these changes from the point of view of identity dynamics refers to various questions such as the considerations and debates the farmers themselves have on "what is a good farmer, nowadays" (Lémery, 2003) or the images that society associates with farmers and the types of relations farmers and other people, notably urbans, have (Bernard et al., 2006). In response to these considerations from inside and outside the profession, new identities emerge (entrepreneur, peasant, multifunctional, agri-rural, high tech, etc.). Lémery (2003) extracted "modern", "traditional" and "alternative" figures from cattle farmers discourses in the French Charolais region in France, and considered a community as a living one when the various figures of professional identities were debated within the community itself.

\subsection{The operation of farming systems and work organisation}

Research scientists working on livestock farming systems have developed a specific approach linking these systems to work organisation (Gibon et al., 1999) considering the farmer as the driver of the company and the work organiser. These two dimensions are therefore considered as "two sides of the same coin" in terms of meeting food and other service objectives, achieving productivity and also taking account of other workrelated elements: expectations relative to living conditions (see below), the need to cope with other activities that may be pivotal to their daily or seasonal organisation, or the subordination of other tasks (Madelrieux and Dedieu, 2008). The farmer thus tries to establish links with other activities within the household that put pressure, and manage the composition and distribution of the workforce, buildings and equipment and agricultural tasks which constitute the operational translation of the farmer's practices (Fig. 4). The need for buffers and adaptive capacities to deal with random events concerns both work organisation and the production system. If it is usual to consider work organisation from the workforce side (externalisation, employees, etc.) or from machinery side, the farming system also integrates the adaptation of livestock and land management to make the system liveable, and aims at understanding the different declinations of "technical management simplifications" at a daily, seasonal or yearly level. 


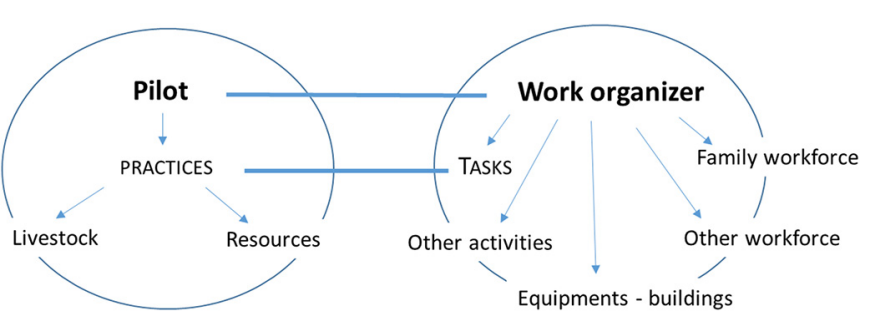

Fig. 4. The two sides of the functioning of a livestock farming system: livestock and resource management, and work organization (from Dedieu and Servière, 2012).

Fig. 4. Les deux faces du fonctionnement d'un système d'élevage : la gestion du troupeau et des ressources, et l'organisation du travail (d'après Dedieu et Servière, 2012).

This framework was developed in two different ways but the objectives remained consistent. The first focused on a timequantitative approach to work, linked to who is doing what, offering indicators of work efficiency and the flexibility of the remaining time available to work organisers (see Cournut et al., 2018). The other characterised the daily form of organisation (who does what, and according to which hierarchy, including private/non-farming activities), adaptations due to the weather, workforce availability (holidays, meetings off the farm), productive events (wintering, harvesting, etc.) and seasonal competition between tasks (on and off the farm) (Madelrieux and Dedieu, 2008). Combinations of these approaches were proposed by Hostiou and Dedieu (2012) and they were included in revised advisory methodologies to explore the needs of farmers regarding their work problems (Dockès et al., 2019). Permanent considerations include: i) an annual approach to work programmes, taking account of different seasons; ii) the differentiation of tasks, primarily as a function of their rhythm (daily or less frequently, etc.) and whether they could be postponed. Routine work with animals, such as twice-daily milking, governs the distribution of and links between tasks (subordination, in parallel); iii) taking account of all workers, whatever their contribution in hours or their relationship with managers (volunteers, salaried employees, etc.).

These approaches can clarify the different drivers of work organisation, whatever their source: on the production side (need to improve productivity, need to change to more environmentally friendly practices; new local food market opportunities) as well as changes to work patterns (an end to the contribution of older volunteers, new off-farm activities during the winter, the introduction of automated equipment, a lack of salaried employees because of the economic profile of the region, etc.). Sraïri et al. (2018) and Bendahan et al. (2018, in this issue) have analysed the implications for the organisation of work of diversifying crop-livestock systems.

\section{Conclusion: Towards an inclusive approach to work}

The drivers of agricultural change will increase pressure on work, whichever area is analysed in the future (employment, health, skills and professional development, farming styles and task/work organisation). The simplest approach at present to address these combined changes is to look at two major dynamics in agriculture: industrialisation and the move towards agroecology.

Industrialisation is guided by the production at low cost of commodities for large markets. Salaried employees, contractors, machines and robots all form part of this industrialisation process. The standardisation of production should also be included, with foreseeable peaks of work. Health regulations (notably with chemicals) linked to highly densified livestock systems or efficient crop monoculture may affect the health of workers. New skills are required for managers (notably workforce management in the short and long-term; Malanski et al., 2019a) and other workers, depending on their tasks and level of responsibilities. If there are numerous salaried employees, then their weekends and holidays must be taken into account, which makes work organisation even more complicated.

The agroecologisation of agriculture is related to familybased systems which sometimes involve older volunteers, the mobilisation of mutual support or temporary employees to cope with peak periods. The diversification of crops, naturebased solutions and direct relationships with consumers (local markets) all form part of this system. The simplicity of the regulations regarding mono-production allows for the development of new skills with particular focus on adaptive capacities, regular monitoring and preventive actions. Frequent encounters with consumers (markets) govern the rhythm of each week. Manual work, which may be physically exacting, remains important insofar as farm machinery manufacturers pay little attention to developing special machines appropriate for agroecologisation and small-scale farming. Long working hours is one of the weaknesses of this type of system.

These examples are of course entirely fictitious and should not be seen as representative of the true situation. However, they well illustrate the links between the work components that underpin the foundations of a farm model. What is now necessary is a broader understanding of the connections between the different dimensions of work we have referred to in this paper, so that we can reflect on the future of work in agriculture. Some important drivers have not been addressed, such as opportunities and tensions in the local labour market or the diversity of farm models at a local scale and interactions between them, including loans of machinery or casual work. Another concerns the opportunities for, and consequences of, off-farm working with respect to both income and working relationships. The local level could be central to developing transversal views on the future of work in agriculture.

\section{References}

Anglade J, Godfroy M, Coquil X. 2018. A device for sharing knowledge and experiences on experimental farm station to sustain the agroecological transition. 13th European IFSA Symposium, 15 July 2018, Chania, Greece. http://ifsa.boku.ac.at/cms/fileadmin/ Proceeding2018/1_Anglade.pdf.

ANSES. 2014. Exposition des travailleurs agricoles aux pesticides. Revue systématique de la littérature scientifique disponible sur les expositions aux pesticides des travailleurs agricoles en France. Document janvier 2014. France : ANSES. https://www.anses.fr/fr/ system/files/AIR2011sa0192Ra-An00.pdf. 
Anzalone G, Purseigle F. 2015. Délegation d'activités et soustraitance: au service de la transmission de l'exploitation ou d'un patrimoine Dans: Gasselin P, Choisis JP, Petit S, Purseigle F, Zasser S, eds. L'agriculture en famille: travailler, réinventer, transmettre. Paris: EDP Sciences, pp. 327-338.

Bánkuti FI, Damasceno JC, Schiavi SM, Kuwaraha KC, Prizon RC. 2018. Structural features, labor conditions and family succession in dairy production systems in Paraná State, Brazil. Cahiers Agricultures 27(4): 45004. DOI: 10.1051/cagri/2018028.

Baudron F, Misiko M, Getnet B, Nazare R, Sariah J, Kaumbutho P. 2019. Labour and mechanisation of African smallholder agriculture: Myths, reality, and implications. Agron Sust Dev, in press.

Beaujeu R, Emlinger C, Greenville J, Jouanjean P. 2019. Emplois, commerce international et internationalisation des filières. Dans : Forget V, Depeyrot JN, Mahé M, Midler E, Hugonnet M, Beaujeu R et al., eds. Actif'Agri. Recompositions des emplois et du travail agricoles. Centre d'étude et de prospective, Ministère de l'agriculture et de l'alimentation. Paris: La Documentation française.

Bendahan AB, Poccard-Chapuis R, Dantas de Medeiros R, de Lucena Costa N, Tourrand JF. 2018. Management and labour in an integrated crop-livestock-forestry system in Roraima, Brazilian Amazonia. Cahiers Agricultures 27(2): 25005. DOI: 10.1051/ cagri/2018014.

Bernard C, Duvernoy I, Dufour A, Albaladejo C. 2006. Les relations sociales des agriculteurs péri-urbains: quelles relations au territoire? Cahiers Agricultures 6(15): 529-534.

Blanpain R, ed. 2015. Protecting labour rights in a multi-polar supply chain and mobile global economy. Alphen aan den Rijn, The Netherlands: Wolters Kluwer.

Brignardello M. 2018. Changes and continuities in agricultural work: The case of small and medium-sized vineyards in Mendoza, Argentina. Cahiers Agricultures 27(3): 35007. DOI: 10.1051/cagri/ 2018025.

Butler D, Holloway L, Baer C. 2012. The impact of technological change in dairy farming: Robotic milking systems and the changing role of the stockperson. Journal of the Royal Agricultural Society of England 173: 1-17.

Caldas de Oliveira C, Augusto de Paula Xavier A, Ulbricht L, Pereira Moro AR, Belinelli MM. 2018. Health in the rural environment: A postural evaluation of milking workers in Brazil. Cahiers Agricultures 27(3): 35004. DOI: 10.1051/cagri/2018021.

Chantre E, Cerf M, Le Bail M. 2015. Transitional pathways towards input reduction on French field crop farms. International Journal of Agricultural Sustainability 13: 69-86.

Chizallet M, Barcellini F, Prost L. 2018. Supporting farmers' management of change towards agroecological practices by focusing on their work: A contribution of ergonomics. Cahiers Agricultures 27(3): 35005. DOI: 10.1051/cagri/2018023.

Coquil X, Dedieu B, Beguin P. 2018a. Professional transitions towards sustainable farming systems: The development of farmers' professional worlds. Work 57(2017): 325-337. DOI: 10.3233/ WOR-172565.

Coquil X, Cerf M, Auricoste C, Joannon A, Barcellini F, Cayre P et al. $2018 \mathrm{~b}$. Questioning the work of farmers, advisors, teachers and researchers in agro-ecological transition. A review. Agron Sust Dev 38(5): 1-11. DOI: 10.1007/s13593-018-0524-4.

Cornwall A, Rivas AM. 2015. From "gender equality" and "women's empowerment" to global justice: Reclaiming a transformative agenda for gender and development. Third World Quarterly 36(2): $1-21$.

Cournut S, Chauvat S, Pastora C, Dos Santos Filho JC, Diéguez F, Hostiou $\mathrm{N}$ et al. 2018. Analyzing work organization on livestock farms by the Work Assessment Method. Agron Sust Dev 38: 58. DOI: $10.1007 / \mathrm{s} 13593-018-0534-2$.

Dahache S. 2014. L'évolution de la place des femmes en agriculture au prisme des rapports familiaux de production. Dans : Gasselin P, Choisis JP, Petit S, Purseigle F, Zasser S, eds. L'agriculture en famille: travailler, réinventer, transmettre. Paris : EDP Sciences, pp. 165-182.

Darnhofer I, Gibbon D, Dedieu B. 2012. Farming systems research: An approach to inquiry. In : Farming systems research into the $21 \mathrm{st}$ century: The new dynamic. Netherlands: Springer.

Dedieu B, Servière G. 2001. Organisation du travail et fonctionnement des systèmes d'élevage. Renc Rech Rum 8: 245-250.

Dedieu B, Servière G. 2012. Vingt ans de recherche-Développement sur le travail en élevage : acquis et perspectives. Inra Productions Animales 25(2): 85-100.

Dedieu B, Damasceno JC. 2016. Complex realities and transformation in work in a diversity of farming models. International Symposium on Work in Agriculture, Maringa, Brazil, 2016. www. workinagriculture.com/IAWA-Activities/International-Sympo sium-on-Work-in-Agriculture-Maringa-Brazil-2016.

Dedieu B, Damasceno JC, Neiman G, Schiavi S, eds. 2019. Multifacet realities of work in agriculture. Cahiers Agricultures, Special Issue. https://www.cahiersagricultures.fr/fr/component/toc/?task=topi c\&id $=883$.

Deffontaines N. 2017. Les suicides des agriculteurs. Pluralité des approches pour une analyse configurationnelle du suicide. Thèse de doctorat, Université de Bourgogne Franche-Comté. Dijon, INRA.

Diao-Camara A. 2013. Le rapport au changement en sociétés pastorales: le cas des éleveurs de Boulal, Tatki et Colonnat (Sénégal). Thèse en sociologie de l'Université de Bourgogne. Dijon, Univ. Bourgogne. https://www.ppzs.org/FichiersComple mentaires/Th\%C3\%A8se\%20Astou\%20Camara.pdf.

Dockès AC, Chauvat S, Correa P, Turlot A, Nettle R. 2019. Advice and advisory roles about work on farms. A review. Agron Sust Dev 39: 2. DOI: $10.1007 / \mathrm{s} 13593-018-0547-\mathrm{x}$.

Doss C. 2018. Women and agricultural productivity: Reframing the issues. Development Policy Research 36: 35-50.

FAO. 2008. Ending poverty and hunger by investing in agriculture and rural areas. Rome, Italy: FAO.

Fiorelli C, Porcher J, Dedieu B. 2010. Improving farm working conditions: A proposal to characterise the individual relationship to work. A case study based on French multi-job-holder sheep farmers. In : Darnhofer I, Grötser M, eds. 9e IFSA Symposium, building sustainable rural future: The added value of systems approaches in times of change and uncertainty, Vienna, 4-6 juillet 2010, pp. 1117-1128.

Forget V, Depeyrot JN, Mahé M, Midler E, Hugonnet M, Beaujeu R et al., eds. 2019a. Actif'Agri. Recompositions des emplois et du travail agricoles. Centre d'études et de prospective, Ministère de l'agriculture et de l'alimentation. Paris: La Documentation française.

Forget V, Grandjean A, Huille A, Legagneux B, Nguyen G, Piet L et al. 2019b. L'emploi et les activités agricoles: chiffres et évolutions clés. Dans : Forget V, Depeyrot JN, Mahé M, Midler E, Hugonnet M, Beaujeu R et al. Actif'Agri. Recompositions des emplois et du travail agricoles. Centre d'études et de prospective, Ministère de l'agriculture et de l'alimentation. Paris: La Documentation française.

Gibon A, Rubino R, Sibbald AR, Sorensen JT, Flament JC, Lhoste P, Revilla R. 1999. Livestock farming systems research in Europe and its potential contribution for managing towards sustainability in livestock farming. Livest Prod Sci 96: 11-31. 
Gras C, Hernández V. 2014. Agribusiness and large-scale farming: Capitalist, globalization in Argentine agriculture. Canadian Journal of Development Studies 35(3): 339-357. DOI: 10.1080/ 02255189.2014 .933702 .

Hervieu B, Purseigle F. 2013. Sociologie des mondes agricoles. Paris : Armand Colin.

Hostiou N, Dedieu B. 2012. A method for assessing work productivity and flexibility in livestock farms. Animal 6(5): 852-862. DOI: 10.1017/S1751731111002084.

Hostiou N, Pham DK, Duteurtre G, Tron Binh V, Dedieu B. 2012. Relationships between work organisation and size of dairy farms: A case study based in Vietnam. Trop Anim Health Prod. DOI: 10.1007/s11250-012-0128-y.

Hostiou N, Fagon J, Chauvat S, Turlot A, Kling F, Boivin X et al. 2017. Impact of precision livestock farming on work and humananimal interactions on dairy farms. A review. Bioscience, Biotechnology and Biochemistry 21: 1-8.

IAWA, International Association on Work in Agriculture. 2018. https://www.workinagriculture.com.

INSERM Expert Report. 2013. Expertise collective pesticides. Effet sur la santé. Synthèse et recommandations. https://www.inserm.fr/ information-en-sante/expertises-collectives/pesticides-effets-sursante.

Lémery B. 2003. Les agriculteurs dans la fabrique d'une nouvelle agriculture. Sociologie du Travail 45(1): 9-25.

Louazel V. 2018. Des agriculteurs sous pression: une profession en souffrance. Rencontres recherches ruminants, Paris, 5-6 décembre 2018. http://www.journees3r.fr/spip.php?article4626.

Lucas V, Gasselin P, Van Der Ploeg JD. 2018. Local inter-farm cooperation: A hidden potential for the agroecological transition in northern agricultures. Agroecology and Sustainable Food Systems 2018: 1-35.

Madelrieux S, Dedieu B. 2008, Qualification and assessment of work organisation in livestock farms. Animal 2(3): 435-447.

Magnan A, Laurent C. 2018. Les publics cibles du conseil santésécurité au travail en agriculture. Rapport INRA-IRES. Grignon : INRA, $115 \mathrm{p}$.

Mahé M, Jacques-Jouvenot D, Gloker O, Quelin C. 2019. La mobilité professionnelle des agriculteurs. Dans: Forget V, Depeyrot JN, Mahé M, Midler E, Hugonnet M, Beaujeu R et al. Actif'Agri. Transformations des emplois et des activités en agriculture. Centre d'études et de prospective, Ministère de l'agriculture et de l'alimentation. Paris: La Documentation française.

Malanski P, Schiavi S, Dedieu B. 2018. Thinking about the future of farming through the different facets of "work in agriculture". Textual analysis of papers from the First Symposium on Work in Agriculture. 13th IFSA Symposium, 1-5 July, Chania (Greece). http://ifsa.boku.ac.at/cms/fileadmin/Proceeding2018/2_Malanski. pdf.

Malanski P, Ingrand S, Hostiou N. 2019a. A new framework to analyze changes in work organization for permanent employees on livestock farms. Agron Sust Dev 39: 12. DOI: 10.1007/s13593-0190557-3.

Malanski P, Schiavi S, Dedieu B. 2019b. Characterizing the "work in agriculture" scientific communities: A bibliometric review. Accepted in Agron Sust Dev.

Nettle R, Kuehne G, Lee K, Armstrong D. 2018. A new framework to analyse workforce contribution to Australian cotton farm adaptability. Agron Sust Dev 38: 38. DOI: 10.1007/s13593-018-0514-6.

Nye C. 2018. The "blind spot" of agricultural research: Labour flexibility, composition and worker availability in the South West of England. Cahiers Agricultures 27(3): 35002. DOI: 10.1051/ cagri/2018018.

Owusu V, Abdulai A, Abdul-rahman S. 2011. Non-farm work and food security among farm households in Northern Ghana. Food Policy 36(2): 108-118.

Parodi G. 2018. Agroecological transition and reconfiguration of horticultural work among family farmers in Buenos Aires, Argentina. Cahiers Agricultures 27(3): 35003. DOI: 10.1051/ cagri/2018020.

Preibisch K. 2010. Pick-your-own labor: Migrant workers and flexibility in canadian agriculture. Int Migr Rev 44: 404-441. DOI: 10.1111/j.1747-7379.2010.00811.x.

RMT Travail en élevage. 2019. http://rmt-travail-elevage.fr/.

Sraïri MT, Bahri S, Ghabiyel Y. 2018. Work management as a means to adapt to constraints in farming systems: A case study from two regions in Morocco. Cahiers Agricultures 27(1): 15007. DOI: 10.1051/cagri/2017066.

Svensson M, Urinboyev R, Wigerfelt-Svensson A, Lundqvist P, Littorin M, Albin M. 2013. Migrant agricultural workers and their socio-economic, occupational and health conditions - A literature review. SSRN. http://dx.doi.org/10.2139/ssrn.2297559.

Van der Ploeg JD. 1994. Styles of farming. An introductory note on concepts and methodology. In : Van der Ploeg JD, Long A, eds. Born from within. Practices and perspectives on endogenous rural development. Assen, Maastrich (The Netherlands): Van Gorcum.

Van der Ploeg JD, Laurent C, Blondeau F, Bonnafous P. 2009. Farm diversity, classification schemes and multifunctionality. Journal of Environmental Management 90: 124-131.

Wane A, Touré I, Njiru N, Diouf Mballo A. 2018. Securing Sahelian pastoralism by using a remunerated workforce for livestock keeping activities: The ambivalence of commodification. Cahiers Agricultures 27(3): 35006. DOI: 10.1051/cagri/2018024.

World Bank. 2018. Agriculture for development. Washington: World Bank.

Zhang QF, Donaldson JA. 2010. From peasants to farmers: Peasant differentiation, labor regimes, and land-rights institutions in China's agrarian transition. Polit Soc 38: 458-489. DOI: 10.1177/0032329210381236.

Zhang X, Yang J, Reardon T. 2017. Mechanization outsourcing clusters and division of labor in Chinese agriculture. China Economic Review 83: 184-195.

Cite this article as: Dedieu B. 2019. Transversal views on work in agriculture. Cah. Agric. 28: 8 . 